\title{
Oil from Asian Bullfrong (Rana tigerina) Skin: Antimicrobial Activity and Its Application in Emulsion Gelatin-based Film
}

\author{
Supatra Karnjanapratum ${ }^{1, *}$, Krisana Nilsuwan², \\ Soottawat Benjakul' ${ }^{2}$, and Punnanee Sumpavapol ${ }^{2}$ \\ ${ }^{I}$ Faculty of Agro-Industry, King Mongkut's Institute of Technology Ladkrabang, Bangkok \\ 10520, Thailand \\ ${ }^{2}$ Department of Food Technology, Faculty of Agro-Industry, Prince of Songkla University, \\ Hat Yai, Songkhla 90112, Thailand \\ *Corresponding author. E-mail: agro_bow@hotmail.com \\ https://doi.org/10.12982/CMUJNS.2019.0006
}

\author{
Received: July 16, 2018 \\ Revised: September 10, 2018 \\ Accepted: September 18, 2018
}

\begin{abstract}
Asian bullfrog (Rana tigerina) has been commonly consumed as meat protein source by Asian people. The certain amount of frog skin was obtained from cutting process line, which could be used as natural source of bioactivity compounds, particularly antimicrobial oil. In the present study, antimicrobial activities of oil extracted from skin of $R$. tigerina against various bacteria were determined using agar-well diffusion assay. The application of the frog oil in emulsion gelatin-based film as antimicrobial packaging was also investigated. Oil from bullfrog skin was extracted and examined for its antibacterial activities on Staphylococcus aureus, Bacillus cereus, Escherichia coli, Vibrio cholera, Aeromonas hydrophil and Salmonella typhimurium. Frog skin oil (FSO) (250-500 mg/ $m L)$ showed inhibitory activities on both Gram +ve (B. cereus) and Gram -ve (E. coli) bacteria with inhibition zone diameters of $8.97-11.50$ and $8.77-11.50 \mathrm{~mm}$, respectively. $A$ gelatin-based film incorporated with frog skin oil emulsion (FSOF) was characterized and it's antibacterial activities were also investigated using agar spot test in comparison with palm oil emulsified film (POF) and fish gelatin (GF) film. Physical characteristics of the three films varied. FSOF was significantly $(P<0.05)$ thicker than $G F$, but thinner than POF. FSOF had higher tensile strength than PO and showed higher elongation at break than $G F(P<0.05)$. Based on water vapor permeability, FSOF could be a good barrier with higher potential than $G F(P<0.05)$, which was comparable to $P O(P>0.05)$. FSOF showed higher transparency value with higher intense of yellow color, compared with those of $P O F$ and GF (P < 0.05). Antimicrobial activity of FSOF was not be detected, which could be accounted for the oil might have been trapped in the film matrix which limited the release of the oil into agar. The extracted oil could be a natural alternative antimicrobial agent. However, further study is required to enhance the release/availability of the oil in emulsion film as antimicrobial agent.
\end{abstract}

Keywords: Asian bullfrog, Extracted oil, Antimicrobial activity, Emulsion, Gelatin-based film 


\section{INTRODUCTION}

Asian bullfrog (Rana tigerina) is commonly farmed in many parts of Thailand for domestic consumption and export (Pariyanonth and Daorerk, 1995). Frog farming has expanded throughout Thailand due to the productive culture and market demand. Frog production has been reported to be approximately 10 tons per day for both local and oversea markets, particularly Hong Kong, Singapore and Taiwan (Wongtavatchai et al., 2003). From the previous study, $R$. tigerina skins could be effectively used for gelatin production with the high gel strength that was comparable to bovine gelatin (Karnjanapratum et al., 2017). The certain amount of released lipid has been observed during pretreatment of skin, and was discarded prior gelatin extraction process. The frog skin oil is a byproduct that might contain high value bioactive compounds, particularly natural antimicrobial compounds. Antimicrobial activity of fatty acids has been reported from several sources including algae (Ikawa, 2004), diatoms (Desbois et al., 2009) and fish (Chitra Som and Radhakrishnan, 2011). Silva et al. (2004) reported that $R$. catesbeiana oil consisted of oleic, linoleic and palmitoleic acid and Méndez et al. (1998) found that fat-storage organ of $R$. catesbeiana contained palmitic $(18.1 \%)$, stearic (4.1\%), myristic (2.7\%), oleic (31.7\%) and linoleic (12.9\%) acids. Alencar et al. (2015) studied antimicrobial activity of nanostructured emulsion based on $R$. catesbeiana oil against fungi and bacteria related to skin diseases. $R$. catesbeiana oils could be a promising candidate for the treatment of infections and might be used to incorporate as antimicrobial drugs.

Emulsion systems have been applied in protein-based gelatin films to improve their physical, barrier and bioactivity properties (Zinoviadou et al., 2010; Tongnuanchan et al., 2014). Several oils including essential oils from different sources have been used for film preparation. Those oils showed antimicrobial and antioxidative properties and could lower water vapor permeability of resulting film (Atares et al., 2010; Tongnuanchan et al., 2014). Palm oil, which is cheaper and has less smell than essential oils, could provide an emulsion gelatin-based film with improved barrier properties, compared with gelatin film (Nilsuwan et al., 2016b). Tongnuanchan et al. (2016) compared films containing palm oil with those incorporated with basil essential oil or the mixture of the two and found that those with palm oil alone had higher seal strength and seal efficiency.

Oil from $R$. catesbeiana frog skin can contain antimicrobial compounds, but there was no information on $R$. tigerina's antimicrobial activity. Its incorporation in emulsion gelatinbased film can be performed to produce active packaging for food industry. This study focused on the possibility of using $R$. tigerina skin oil, which is generally a byproduct in frog farming in Thailand, as a new natural preservative that could be used in active packaging.

\section{MATERIALS AND METHODS}

\section{Chemicals}

All chemicals were of analytical grade. Chloroform, methanol, sodium sulfate and glycerol were obtained from Merck (Darmstadt, Germany). Sodium chloride, tetracycline and soy lecithin (L- $\alpha$-phosphatidylcholine, HLB 4.0) were purchased from Sigma-Aldrich Chemical Co. (St. Louis, MO, USA). Fish gelatin produced from tilapia skin ( 240 bloom) was procured from Lapi Gelatine S.p.A (Empoli, Italy). Palm oil was obtained from Oleen Co., Ltd. (Samutsakorn, Thailand). 


\section{Materials}

Skins of Asian bullfrog (Rana tigerina) weighing 200-300 g each were obtained from a farm in Hat Yai, Songkhla, Thailand. Skins were kept in a polystyrene box containing ice using a skin/ice ratio 1:2 (w/w) and transported to the Department of Food Technology, Prince of Songkla University, Hat Yai, within $1 \mathrm{~h}$. Upon arrival, the skins were washed with iced tap water $\left(1-3{ }^{\circ} \mathrm{C}\right)$ and pooled as a composite sample in polyethylene bags and stored at $-20{ }^{\circ} \mathrm{C}$ until used. The storage time was less than 2 months. Prior to oil extraction, frozen skins were cut into small pieces (about $1 \times 1 \mathrm{~cm}^{2}$ ) using scissors and pulverized in the presence of liquid nitrogen in a blender (Phillips, Guangzhou, China).

\section{Extraction of frog skin oil}

Frog skin oil (FSO) was extracted according to the method of Bligh and Dyer (1959). Samples $(100 \mathrm{~g})$ were homogenised with $800 \mathrm{~mL}$ of a mixture of chloroform: methanol: water $(1: 2: 1, \mathrm{v} / \mathrm{v} / \mathrm{v})$ at $11,000 \mathrm{rpm}$ for $1 \mathrm{~min}$. To the homogenate, $200 \mathrm{~mL}$ of chloroform was added and the mixtures were homogenized for $1 \mathrm{~min}$. Thereafter, $100 \mathrm{~mL}$ of water was added and the mixtures were homogenised for $30 \mathrm{~s}$ at the same speed. The mixture was filtered through a Whatman No. 4 filter paper (Whatman International Ltd., Maidstone, UK) and the filtrate was transferred into a separating funnel where the chloroform phase (bottom phase) was drained off into an Erlenmeyer flask. Sodium sulfate (anhydrous) (10-12 g) was added and the mixture was shaken thoroughly to remove the residual water. Lipid in chloroform was decanted into a round-bottomed flask through a filter paper (Whatman No. 4). The chloroform was evaporated at $45^{\circ} \mathrm{C}$ using a rotary evaporator (Rotavapor, model R-14, Büchi, Tokyo, Japan). The residual solvent was removed by flushing with nitrogen. The lipid was transferred to an amber vial and the sample was kept under a nitrogen atmosphere at $-20^{\circ} \mathrm{C}$ until analyzed.

\section{Antimicrobial activity of frog skin oil (FSO)}

Bacterial cultures. Pathogenic bacteria used as test organisms in this study were Bacillus cereus DMST 5040, Escherichia coli DMST 4212, Salmonella Typhimurium DMST 562, Staphylococcus aureus DMST 8840, Vibrio choleraenon O1/non O139 DMST 2873 and Aeromonas hydrophila TISTR 1321. They were obtained from the Department of Medical Sciences, Ministry of Public Health, Thailand (DMST), and Thailand Institute of Scientific and Technological Research (TISTR). The bacterial strains were sub-cultured twice in nutrient broth at $37^{\circ} \mathrm{C}$ for $18 \mathrm{~h}$ and the density of an inoculum was adjusted to the turbidity of 0.5 McFarland standard $\left(10^{5}-10^{6} \mathrm{CFU} / \mathrm{mL}\right)$ before being used (Canillac and Mourey, 2001).

Agar-well diffusion assay. The antimicrobial activity of FSO was determined by agarwell diffusion assay as described by Wonghirundecha and Sumpavapol (2012). One milliliter of freshly prepared inoculum was aseptically added to a $9 \mathrm{~mL}$ of sterilized Muller-Hinton soft medium $(0.75 \%$ agar, w/v), immediately mixed, poured into a Petri dish and left to solidify at room temperature. After being dried for $15 \mathrm{~min}$ in laminar air flow, 4 wells ( $6 \mathrm{~mm}$ in diameter) were made in each plate. Each well was filled with $20 \mu \mathrm{L}$ of FSO $(250$ and $500 \mathrm{mg} / \mathrm{mL})$, acetone (negative control) and $0.5 \mathrm{mg} / \mathrm{mL}$ of tetracycline (positive control). Plates were left at room temperature for $30 \mathrm{~min}$ to allow diffusion of material in media and were incubated at $37^{\circ} \mathrm{C}$. After $24 \mathrm{~h}$ of incubation, the inhibition zones around wells were measured in $\mathrm{mm}$ using a Vernier caliper. The absence of an inhibition zone was interpreted as negative (no antimicrobial activity). The experiment was repeated three times. 


\section{Impact of frog skin oil on characteristics of emulsion gelatin-based film and its antimicrobial activity}

Preparation of film forming solution and emulsion. Film forming solution (FFS) and film forming emulsion (FFE) from fish gelatin were prepared according to the method of Tongnuanchan et al. (2016). Gelatin powder was mixed with distilled water to obtain a protein content of $3.5 \%$ (wet basis) and the mixture was heated at $70^{\circ} \mathrm{C}$ for $30 \mathrm{~min}$. Glycerol at a concentration of $30 \%(\mathrm{w} / \mathrm{w}$, based on protein content) was added into solution. The resulting solution was termed as 'film forming solution' (FFS). To prepare the film forming emulsion, palm oil (PO) and frog skin oil (FSO) FFS was mixed with Tween-20, as a surfactant (25\%, based on oil content), which was then transferred into the prepared gelatin solution to obtain $50 \%$ of oil concentration (w/w, based on protein content). The mixture was homogenized at 22,000 rpm for $3 \mathrm{~min}$ using a rotor-stator homogenizer (IKA Labortechnik homogenizer, Selangor, Malaysia). The emulsion was referred to 'film forming emulsion' (FFE). Both film forming solution and emulsion were used for film preparation.

Preparation of film. To prepare the films, the FFS and FFE ( $4 \mathrm{~g})$ was cast onto a rimmed silicone resin plate $\left(50 \times 50 \mathrm{~mm}^{2}\right)$ and air-blown at room temperature for $12 \mathrm{~h}$. The films were further dried at $25{ }^{\circ} \mathrm{C}$ and $50 \pm 5 \% \mathrm{RH}$ for $24 \mathrm{~h}$ in an environmental chamber (WTB Binder, Tuttlingen, Germany). The resulting films were manually peeled off and subjected to analyses. Gelatin film, palm oil/gelatin film and FSO/gelatin film were termed GF, POF and FSOF, respectively.

Film analyses. Film thickness. The thickness of film was measured using a micrometer (Mitutoyo, Model ID-C112PM, Serial No. 00320, Mitutoyo Corp., Kawasaki-shi, Japan). Five random locations around each film of ten film samples were used for determination of average thickness.

Mechanical properties. Prior to testing the mechanical properties, films were conditioned for $48 \mathrm{~h}$ at $25^{\circ} \mathrm{C}$ and $50 \pm 5 \% \mathrm{RH}$. Tensile strength (TS) and elongation at break (EAB) were determined as described by Iwata et al. (2000) using the Universal Testing Machine (Lloyd Instrument, Hampshire, UK) equipped with tensile load cell of $100 \mathrm{~N}$. Ten samples $(20 \times 50$ $\mathrm{mm}^{2}$ ) with an initial grip length of $30 \mathrm{~mm}$ were used for testing. Cross-head speed was set at 30 $\mathrm{mm} / \mathrm{min}$. Tensile strength ( $\mathrm{MPa}$ ) was calculated by dividing the maximum load $(\mathrm{N})$ necessary to pull the sample film apart by the cross-sectional area $\left(\mathrm{m}^{2}\right)$. Average thickness of the film strip was used to estimate the cross-sectional area of the sample. Percentage elongation at break was calculated by dividing film elongation at the moment of rupture by the initial grip length of samples. The value was then multiplied by 100 .

Water vapor permeability (WVP). Shiku et al. (2004) mentioned that films were sealed on an aluminium permeation cup containing dried silica gel $(0 \% \mathrm{RH})$ with silicone vacuum grease and a rubber gasket to hold the films in place. The cups were placed in an environmental chamber at $25 \pm 0.5^{\circ} \mathrm{C}$ and $50 \pm 5 \% \mathrm{RH}$. The cups were weighed at 1-h interval over a 10 -h period. WVP of the film was calculated as follows:

$$
\mathrm{WVP}(\mathrm{g} / \mathrm{m} \mathrm{s} \mathrm{Pa})=\frac{w l}{\operatorname{At}\left(P_{2}-P_{1}\right)}
$$

where $\mathrm{w}$ is the weight gain of the cup $(\mathrm{g}) ; 1$ is the film thickness $(\mathrm{m})$; $\mathrm{A}$ is the exposed area of film $\left(\mathrm{m}^{2}\right)$; $\mathrm{t}$ is the time of gain ( $\left.\mathrm{s}\right)$; P2-P1 is the vapor pressure difference across the film (1583.7 $\mathrm{Pa}$ at $25^{\circ} \mathrm{C}$ ). 
Color. Film samples were subjected to color measurement using a CIE colorimeter (Hunter associates laboratory, Inc., Reston, VA, USA). D65 (day light) and a measure cell with opening of $30 \mathrm{~mm}$ was used. The color of the films was expressed as L*-value (lightness), $\mathrm{a}^{*}$ value (redness/greenness) and $\mathrm{b}^{*}$-value (yellowness/blueness). Total difference of color $\left(\Delta \mathrm{E}^{*}\right)$ was calculated as follows (Gennadios et al., 1996):

$$
\Delta E^{*}=\sqrt{\left(\Delta L^{*}\right)^{2}+\left(\Delta a^{*}\right)^{2}+\left(\Delta b^{*}\right)^{2}}
$$

where $\Delta \mathrm{L}^{*}, \Delta \mathrm{a}^{*}$ and $\Delta \mathrm{b}^{*}$ are the differences between the color parameter of the samples and those of the white standard $\left(\mathrm{L}^{*}=92.80, \mathrm{a}^{*}=-1.26, \mathrm{~b}^{*}=0.55\right)$.

Light transmittance and transparency value. The light transmittance of films was measured at the ultraviolet and visible range (200-800 $\mathrm{nm}$ ) using a UV-vis spectrophotometer (UV-1800, Shimadzu, Kyoto, Japan) according to the method of Shiku et al. (2004). The transparency value of film was calculated using the following equation (Han and Floros, 1997):

$$
\text { Transparency value }=\frac{-\log T_{600}}{x}
$$

where $\mathrm{T}_{600}$ is the fractional transmittance at $600 \mathrm{~nm}$ and $\mathrm{x}$ is the film thickness $(\mathrm{mm})$. The greater transparency value represents the lower transparency of film.

Antimicrobial activity of frog skin oil emulsion-based film (FSOF). Antimicrobial activity of FSOF was evaluated using agar spot test as described by Buntin et al. (2008) with slight modification. FSOF was cut into discs (5.5 $\mathrm{mm}$ in diameter) using a paper cutter. The selected bacteria strain (Bacillus cereus DMST 5040 and Escherichia coli DMST 4212) were inoculated into Muller-Hinton soft medium (MHA). Then the FSOF discs were placed on the inoculated MHA agar. After incubation at $37^{\circ} \mathrm{C}$ for $24 \mathrm{~h}$, the inhibition zone was examined around the FSOF disc. Antimicrobial activity of POF and GF was tested in the same manner.

\section{Statistical analysis}

Experiments were run in triplicate using three lots of samples. Data were subjected to analysis of variance (ANOVA). Comparison of means was carried out by the Duncan's multiple range test (Steel et al., 1980). Statistical analysis was performed using the Statistical Package for Social Science (SPSS 11.0 for windows, SPSS Inc., Chicago, IL, USA). 


\section{RESULTS}

\section{Antimicrobial activity of frog skin oil}

The positive control, tetracycline, clearly inhibited all the bacteria tested, giving a clear zone around the well range from 17.27 to $24.60 \mathrm{~mm}$ (Table 1). Acetone, used as a negative control, had no inhibition effect on all bacteria tested. It was noted that $R$. tigerina skin oil exhibited an inhibition zone against only B. cereus and E. coli, at both concentrations tested ( 250 and $500 \mathrm{mg} / \mathrm{mL}$ ). B. cereus is Gram positive and E. coli is Gram negative, which indicated the broad spectrum of inhibition activity of FSO.

Table 1. Antimicrobial activity of $R$. tigerina skin oil.

\begin{tabular}{lcccc}
\hline \multirow{2}{*}{ Microbial } & \multirow{2}{*}{ Type of bacteria } & \multicolumn{3}{c}{ Inhibition zone diameter (mm) } \\
\cline { 3 - 5 } & & $\mathbf{2 5 0} \mathbf{~} \mathbf{~ g} / \mathbf{m L}$ & $\mathbf{5 0 0} \mathbf{~} \mathbf{~ g} \mathbf{m L}$ & Positive control \\
\hline Staphylococcus aureus & Gram +ve & nd & nd & $18.67 \pm 0.72$ \\
Bacillus cereus & Gram +ve & $8.97 \pm 0.45$ & $11.50 \pm 0.50$ & $23.20 \pm 1.47$ \\
Escherichia coli & Gram -ve & $8.77 \pm 0.25$ & $11.50 \pm 0.50$ & $24.60 \pm 0.40$ \\
Vibrio cholera & Gram -ve & nd & nd & $17.27 \pm 0.97$ \\
Aeromonas hydrophil & Gram -ve & nd & nd & $17.50 \pm 0.70$ \\
Salmonella typhimurium & Gram -ve & nd & nd & $9.93 \pm 0.31$ \\
\hline
\end{tabular}

Note: nd; Not detected. $250 \mathrm{mg} / \mathrm{mL}$ and $500 \mathrm{mg} / \mathrm{mL}$; Concentration of frog skin oil tested. Positive control; $0.5 \mathrm{mg} / \mathrm{mL}$ of tetracycline.

Impact of frog skin oil on characteristics of emulsion gelatin-based film and its antimicrobial activity

Characteristics of frog skin oil emulsion film. Film appearance and thickness. In general, GF was colorless and transparent, while POF and FSOF were more opaque (Figure 1). Between the emulsion films, FSOF had lower film thickness than POF $(P<0.05)$. However, both emulsion films showed the higher thickness than GF $(P<0.05)$. Therefore, the addition of different oils had the impact on the appearance and thickness of the resulting gelatin film.

\begin{tabular}{c|cc}
\hline \multicolumn{5}{c}{ Film samples } \\
\hline GF & POF \\
\hline
\end{tabular}

Figure 1. Photographs of gelatin film (GF), palm oil/gelatin film (POF) and frog skin oil/ gelatin film (FSOF). 
Mechanical properties. POF exhibited lower tensile strength (TS) than GF $(P<0.05)$ (Table 2). Palm oil droplets were able to insert themselves between gelatin chains, thereby lowering the intramolecular and intermolecular bondings as indicated by lowered TS. However, no difference of TS between GF and FSOF was observed $(P>0.05)$. Furthermore, the highest elongation at break point occurred for POF followed by FSOF and GF, respectively $(P<0.05)$. This indicated that PO and FSO might have different compositions, which had to further investigate. Thus, the mechanical properties of resulting gelatin film were improved by the incorporation of FSO.

Table 2. Characteristics of frog skin oil/gelatin film.

\begin{tabular}{|c|c|c|c|c|}
\hline Films & $\begin{array}{l}\text { Thickness } \\
\text { (mm) }\end{array}$ & $\begin{array}{c}\text { Tensile strength } \\
\text { (MPa) }\end{array}$ & $\begin{array}{c}\text { Elongation at break } \\
(\%)\end{array}$ & $\begin{array}{c}\text { Water vapor } \\
\text { permeability } \\
\left(\times 10^{-10} \mathrm{~g} \mathrm{~m} / \mathbf{m}^{2} \mathbf{s} \mathrm{Pa}\right)\end{array}$ \\
\hline GF & $0.050 \pm 0.002 \mathrm{c}$ & $27.19 \pm 0.64 \mathrm{a}$ & $15.67 \pm 1.57 \mathrm{c}$ & $1.53 \pm 0.05 \mathrm{a}$ \\
\hline POF & $0.086 \pm 0.002 \mathrm{a}$ & $20.11 \pm 1.30 \mathrm{~b}$ & $48.23 \pm 1.11 \mathrm{a}$ & $1.40 \pm 0.04 b$ \\
\hline FSOF & $0.075 \pm 0.002 b$ & $26.61 \pm 3.15 \mathrm{a}$ & $40.82 \pm 4.03 b$ & $1.37 \pm 0.04 b$ \\
\hline
\end{tabular}

Note: GF: Gelatin film; POF: Palm oil/gelatin film; FSOF: FSO/gelatin film. Different lowercase letters in the same column indicated significant difference $(P \leq 0.05)$.

Water vapor permeability (WVP). Lower WVP was found for both emulsified films in comparison with GF $(P<0.05)$ (Table 2$)$. No difference WVP between FSOF and POF was observed $(P>0.05)$. Therefore, the incorporation of oils into gelatin-based film directly affected WVP of resulting films.

Table 3. Color of frog skin oil/gelatin film.

\begin{tabular}{lccccc}
\hline Films & $\boldsymbol{L}^{*}$ & $\boldsymbol{a}^{*}$ & $\boldsymbol{b}^{*}$ & $\Delta \boldsymbol{E}^{*}$ & $\begin{array}{c}\text { Transparency } \\
\text { value }\end{array}$ \\
\hline GF & $90.15 \pm 0.16 \mathrm{a}$ & $-1.42 \pm 0.01 \mathrm{a}$ & $1.49 \pm 0.04 \mathrm{c}$ & $2.82 \pm 0.16 \mathrm{c}$ & $1.30 \pm 0.07 \mathrm{c}$ \\
POF & $90.38 \pm 0.35 \mathrm{a}$ & $-1.89 \pm 0.02 \mathrm{~b}$ & $3.23 \pm 0.06 \mathrm{~b}$ & $3.67 \pm 0.21 \mathrm{~b}$ & $5.27 \pm 0.13 \mathrm{a}$ \\
FSOF & $87.61 \pm 0.28 \mathrm{~b}$ & $-3.94 \pm 0.07 \mathrm{c}$ & $19.52 \pm 0.64 \mathrm{a}$ & $19.85 \pm 0.60 \mathrm{a}$ & $3.00 \pm 0.17 \mathrm{~b}$ \\
\hline
\end{tabular}

Note: Values are given as the mean $\pm \mathrm{SD}(n=3)$. GF: Gelatin film; POF: Palm oil/gelatin film; FSOF: FSO/ gelatin film. Different lowercase letters in the same column indicated significantly different $(P<0.05)$.

Color. Color of GF, POF and FSOF is shown in Table 3. In general, the lowest $\mathrm{L}^{*}$-value was found for FSOF $(P<0.05)$ while similar $\mathrm{L}^{*}$-value was found for GF and POF $(P>0.05)$. Both emulsified films showed lower $\mathrm{a}^{*}$-value but higher $\mathrm{b}^{*}$ and $\Delta \mathrm{E}^{*}$ than $\mathrm{GF}(P<0.05)$. The highest $\mathrm{b}^{*}$-value and $\Delta \mathrm{E}^{*}$ were obtained from FSOF $(P<0.05)$. Therefore, incorporation of different oils had an impact on the color of resulting film.

Light transmission and transparency value. FSOF had lower light transmission in comparison with GF but higher than the POF at all wavelengths (Figure 2). The addition of oils generally impeded the light transmission through the film probably due to the light scattering at the interface of oil droplets imbedded in the film matrix. The lower transparency value indicated that the film was more transparent. POF showed higher transparency value 
than the other films $(P<0.05)$ (Table 2$)$, which suggested that the addition of PO made films less transparent. Therefore, the addition of FSO yielded the film with appropriate UV-light transmission and less opaqueness in the resulting film, compared with the use of palm oil.

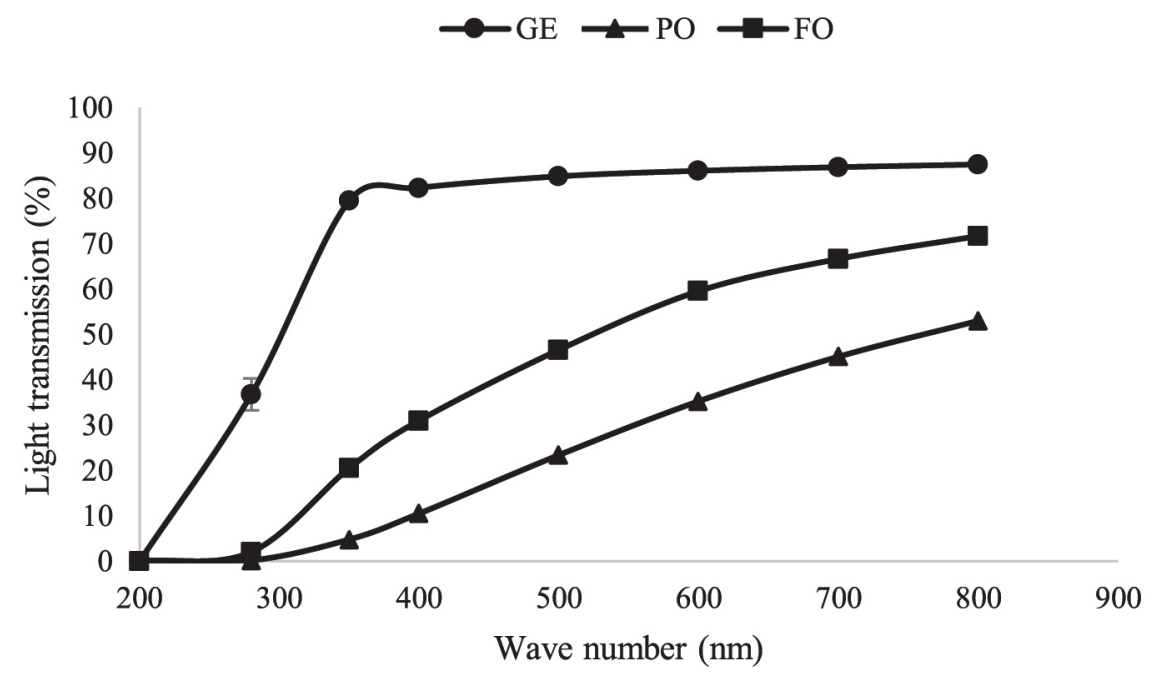

Figure 2. Light transmission of gelatin film (GF: - - $)$; palm oil/gelatin film (POF: $\longrightarrow$ - $)$ and frog skin oil/gelatin film (FSOF: - -).

Antimicrobial activity of frog skin oil/gelatin emulsion-based film (FSOF). Antimicrobial activity of FSOF was examined against B. cereus and E. coli, which showed the positive result with FSO using agar-well diffusion method. Inhibition activity of FSOF was tested in comparison with POF and GF. Nevertheless, no inhibition zone was detected from all the films tested (data not shown). Under the condition used, FSOF had no antimicrobial properties since FSO could not be released from the film matrix and diffuse into hydrophilic phase of the MHA agar.

\section{DISCUSSION}

$R$. tigerina skin oil exhibited an inhibition zone against Gram positive and negative bacteria. The result was in agreement with Chitra Som and Radhakrishnan (2011) who found that the oil extracted from sardine fish could inhibit Gram positive (Staphylococcus aureus and Enterococcous feacalis) and Gram negative (E. coli and Pseudomonas aeruginosa) bacteria as indicated by a wide inhibition zone. Chitra Som and Radhakrishnan (2011) showed different bacterial inhibition activity of Sardinella logiceps and S. fimbriata extracted oils, mainly attributed to the disparity in docosahexaenoic acid (DHA) content. Alencar et al. (2015) found that some esters of palmitic and oleic acids, $\alpha$-curcumene, $\alpha$-himachalene, isothujol and $\alpha$-fenchene inhibited some strains of Staphylococcus, Pseudomonas, and Candida. Antimicrobial activity of FSO was more likely governed by its lipid composition. 
The different characteristics of frog skin oil emulsion film were obtained, compared with those from gelatin film (GF), palm oil/gelatin film (POF). Tongnuanchan et al. (2016) who reported that the emulsion film containing basil essential oil, palm oil, and oil mixture (1:1) were thicker than the control gelatin film. Oil droplets were dispersed and localized in the protein film network, thereby lowering the interaction between protein molecules. The extended film network was developed as indicated by the increased film thickness. FSO droplets distribution throughout the film matrix might interact with gelatin matrix to some degree. This might lower impact on disruption on chain to chain interaction during film formation (Nilsuwan et al., 2016a). FSOF exhibited the moderate elongation at break (EAB) between GF and POF, which suggests that the oil droplets are localized between protein chains and acted as plasticizer, rendering the films more flexible as indicated by higher EAB in comparison with GF (Perez-Gago and Krochta, 2001; Nilsuwan et al., 2016a). The gelatin-based film generally had poor water vapor barrier property (Jongjareonrak et al., 2006). This drawback was improved by incorporation of hydrophobic compounds such as oil as demonstrated by lower water vapor permeability of emulsified films (Tongnuanchan et al., 2012). The presence of hydrophobic disperse phase limits water vapor transfer since it increases the tortuosity factor (Atares et al., 2010). The addition of oils especially FSO contributed the dark yellowish to the gelatin-based film. The coloring pigments/compounds and their contents in oil caused the color change in gelatin film (Tongnuanchan et al., 2014). All resulting films had a good barrier property in the UV-ranges (200-280 nm). The higher UV light barrier capacity was previously reported for films from bigeye snapper and brown stripe red snapper skins (Jongjareonrak et al., 2006). Basically, oil droplets localized in the film matrix lowered the transparency of gelatin films (Tongnuanchan et al., 2012).

In the present study, antimicrobial activity of FSOF could not be detected by agar-well diffusion method. Cagri et al. (2001) previously demonstrated that antimicrobial activity by diffusion of antimicrobials from the film disk depends on the size, shape, and polarity of the diffusing molecule, as well as the chemical structure of the film. Jongjareonrak et al. (2008) also described interactions between active compounds and the film matrix via some bondings that can possibly cause in the lowered release of those active compounds.

\section{CONCLUSION}

Oil extracted from Asian bullfrog skin could be an alternative natural source of antimicrobial compounds that possess inhibition activity on both gram positive (B. cereus) and gram negative (E. coli) bacteria. FSOF showed slightly different characteristics from POF and GF. However, no antimicrobial activity of FSOF could be detected, which might be due to the limited release of FSO from film matrix. Further study should be focused on the enhancement of the release/availability of antimicrobial compounds of FSO from the films. 


\section{ACKNOWLEDGEMENTS}

The authors would also like to express their appreciation to the Thailand Research Fund (TRF) under Research Grant for New Scholar (MRG) to Dr. Supatra Karnjanapratum for support. The KMITL Research Fund was acknowledged for the financial support through Research Seed Grant for New Lecturer (KREF186014). The authors would also like to thank Professor Dr. Anthony Keith Thompson, Visiting Professor under Academic Melting Pot program at Faculty of Agro-Industry, King Mongkut's Institute of Technology Ladkrabang, for invaluable suggestions and corrections.

\section{REFERENCES}

Alencar, E.N., Xavier-Junior, F.H., Morais, A.R., Dantas, T.R.F., Dantas-Santos, N., Verissimo, L.M., Rehder, V.L.G., Chaves, G.M., Oliveira, A.G., and Egito, E.S. 2015. Chemical characterization and antimicrobial activity evaluation of natural oil nanostructured emulsions. Journal of Nanoscience and Nanotechnology. 15(1): 880-888.

ASTM. 1989. Annual book of ASTM standards. American Society for Testing and Materials, Philadelphia, PA, USA.

Atares, L., Bonilla, J., and Chiralt, A. 2010. Characterization of sodium caseinate-based edible films incorporated with cinnamon or ginger essential oils. Journal of Food Engineering. 100(4): 678-687. https://doi.org/10.1016/j.jfoodeng.2010.05.018

Bligh, E.G., and Dyer, W.J. 1959. A rapid method of total lipid extraction and purification. Canadian Journal of Biochemistry and Physiology. 37(8): 911-917. https://doi. org/10.1139/o59-099

Buntin, N., Chanthachum, S., and Hongpattarakere, T. 2008. Screening of lactic acid bacteria from gastrointestinal tracts of marine fish for their potential use as probiotics. Songklanakarin Journal of Science and Technology. 30: 141-148.

Cagri, A., Ustunol, Z., and Ryser, E.T. 2001. Antimicrobial, mechanical, and moisture barrier properties of low $\mathrm{pH}$ whey protein-based edible films containing p-aminobenzoic or sorbic acids. Journal of Food Science. 66(6): 865-870. https://doi. org/10.1111/j.1365-2621.2001.tb15188.x

Canillac, N., and Mourey, A. 2001. Antibacterial activity of the essential oil of Picea excelsa on Listeria, Staphylococcus aureus and coliform bacteria. Food Microbiology. 18(3): 261-268. https://doi.org/10.1006/fmic.2000.0397

Chitra Som, R.S., and Radhakrishnan, C.K. 2011. Antibacterial activities of polyunsaturated fatty acid extracts from Sardinella longiceps and Sardinella fimbriata. Indian Journal of Geo-Marine Sciences. 40(5): 710-716.

Desbois, A.P., Mearns-Spragg, A., and Smith, V.J. 2009. A fatty acid from the diatom Phaeodactylum tricornutum is antibacterial against diverse bacteria including multiresistant Staphylococcus aureus (MRSA). Marine Biotechnology. 11(1): 45-52. https:// doi.org/10.1007/s10126-008-9118-5 
Gennadios, A., Weller, C.L., Hanna, M.A., and Froning, G.W. 1996. Mechanical and barrier properties of egg albumen films. Journal of Food Science. 61(3): 585-589. https://doi. org/10.1111/j.1365-2621.1996.tb13164.x

Han, J.H., and Floros, J.D. 1997. Casting antimicrobial packaging films and measuring their physical properties and antimicrobial activity. Journal of Plastic Film and Sheeting. 13(4): 287-298. https://doi.org/10.1177/875608799701300405

Ikawa, M. 2004. Algal polyunsaturated fatty acids and effects on plankton ecology and other organisms. UNH Center for Freshwater Biology Research. 6(2): 17-44.

Iwata, K.I., Ishizaki, S.H., Handa, A.K., and Tanaka, M.U. 2000. Preparation and characterization of edible films from fish water-soluble proteins. Fisheries Science. 66(2): 372-378. https://doi.org/10.1046/j.1444-2906.2000.00057.x

Jongjareonrak, A., Benjakul, S., Visessanguan, W., Prodpran, T., and Tanaka, M. 2006. Characterization of edible films from skin gelatin of brownstripe red snapper and bigeye snapper. Food Hydrocolloids. 20(4): 492-501. https://doi.org/10.1016/j. foodhyd.2005.04.007

Jongjareonrak, A., Benjakul, S., Visessanguan, W., and Tanaka, M. 2008. Antioxidative activity and properties of fish skin gelatin films incorporated with BHT and $\alpha$-tocopherol. Food Hydrocolloids. 22(3): 449-458. https://doi.org/10.1016/j.foodhyd.2007.01.002

Karnjanapratum, S., Sinthusamran, S., Sae-leaw, T., Benjakul, S., and Kishimura, H. 2017. Characteristics and gel properties of gelatin from skin of Asian bullfrog (Rana tigerina). Food Biophysics. 12(3): 289-298. https://doi.org/10.1007/s11483-017-9485-4

Méndez, E., Sanhuez, J., Nieto, S., Speisky, H., and Valenzuela, A. 1998. Fatty acid composition, extraction, fractionation, and stabilization of bullfrog (Rana catesbeiana) oil. Journal of the American Oil Chemists' Society. 75: 79-83. https://doi.org/10.1007/ s11746-998-0012-0

Nilsuwan, K., Benjakul, S., and Prodpran, T. 2016a. Effects of soy lecithin levels and microfluidization conditions on properties of fish gelatin-based film incorporated with palm oil. International Journal of Food Engineering. 12(7): 647-660. https://doi. org/10.1515/ijfe-2016-0064

Nilsuwan, K., Benjakul, S., and Prodpran, T. 2016b. Influence of palm oil and glycerol on properties of fish skin gelatin-based films. Journal of Food Science and Technology. 53(6): 2715-2724. https://doi.org/10.1007/s13197-016-2243-7

Pariyanonth, P., and Daorerk, V. 1995. Frog farming in Thailand. 25-28.

Perez-Gago, M.B., and Krochta, J.M. 2001. Lipid particle size effect on water vapor permeability and mechanical properties of whey protein/beeswax emulsion films. Journal of Agricultural and Food Chemistry. 49(2): 996-1002. https://doi.org/10.1021/ jf000615f

Shiku, Y., Hamaguchi, P.Y., Benjakul, S., Visessanguan, W., and Tanaka, M. 2004. Effect of surimi quality on properties of edible films based on Alaska pollack. Food Chemistry. 86(4): 493-499. https://doi.org/10.1016/j.foodchem.2003.09.022

Silva, L.P., Miyasaka, C.K., Martins, E.F., Leite, J., Lacava, Z.G.M., Curi, R., and Azevedo, R.B. 2004. Effect of bullfrog (Rana catesbeiana) oil administered by gavage on the fatty acid composition and oxidative stress of mouse liver. Brazilian Journal of Medical and Biological Research. 3(10): 1491-1496. https://doi.org/10.1590/S0100879X2004001000007 
Steel, R.G.D., Torrie, J.H., and Dicky, D.A. 1980. Principles and procedures of statistics: A biometrical aproach. McGraw-Hill, New York.

Tongnuanchan, P., Benjakul, S., and Prodpran, T. 2012. Properties and antioxidant activity of fish skin gelatin film incorporated with citrus essential oils. Food Chemistry. 134(3): 1571-1579. https://doi.org/10.1016/j.foodchem.2012.03.094

Tongnuanchan, P., Benjakul, S., and Prodpran, T. 2014. Comparative studies on properties and antioxidative activity of fish skin gelatin films incorporated with essential oils from various sources. International Aquatic Research. 6(2): 62. https://doi.org/10.1007/ s40071-014-0062-x

Tongnuanchan, P., Benjakul, S., Prodpran, T., Pisuchpen, S., and Osako, K. 2016. Mechanical, thermal and heat sealing properties of fish skin gelatin film containing palm oil and basil essential oil with different surfactants. Food Hydrocolloids. 56: 93-107. https:// doi.org/10.1016/j.foodhyd.2015.12.005

Wonghirundecha, S., and Sumpavapol, P. 2012. Antibacterial activity of selected plant byproducts against food-borne pathogenic bacteria. In: 2012 International Conference on Nutrition and Food Sciences IPCBEE (1 $11^{\text {th }}$ ed., Vol. 39). Singapore: IACSIT Press.

Wongtavatchai, J., Rungsipipat, A., Chumkaeo, A., and Surachetpong, W. 2003. Common diseases of farmed frogs Rana tigerina in thailand. In: Proceedings $11^{\text {th }}$ International Symposium of the World Association of Veterinary Laboratory Diagnosticians and OIE Seminar on Biotechnology. Bangkok, Thailand: Thai Veterinary Medical Association.

Zinoviadou, K.G., Koutsoumanis, K.P., and Biliaderis, C.G. 2010. Physical and thermomechanical properties of whey protein isolate films containing antimicrobials, and their effect against spoilage flora of fresh beef. Food Hydrocolloids. 24(1): 49-59. https:// doi.org/10.1016/j.foodhyd.2009.08.003 